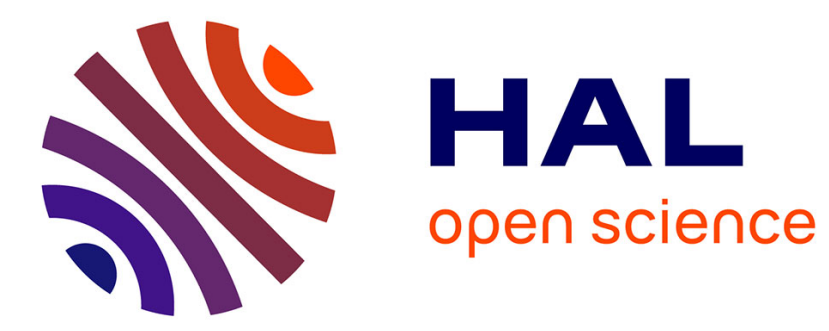

\title{
Chiral ferrocenyl diphosphines for asymmetric transfer hydrogenation of acetophenone
}

Jérôme Cabou, Jacques S. Brocard, Lydie Pélinski

\section{To cite this version:}

Jérôme Cabou, Jacques S. Brocard, Lydie Pélinski. Chiral ferrocenyl diphosphines for asymmetric transfer hydrogenation of acetophenone. Tetrahedron Letters, 2005, 46, pp.1185-1188. 10.1016/j.tetlet.2004.12.059 . hal-00115517

\section{HAL Id: hal-00115517 https://hal.science/hal-00115517}

Submitted on 21 Nov 2006

HAL is a multi-disciplinary open access archive for the deposit and dissemination of scientific research documents, whether they are published or not. The documents may come from teaching and research institutions in France or abroad, or from public or private research centers.
L'archive ouverte pluridisciplinaire HAL, est destinée au dépôt et à la diffusion de documents scientifiques de niveau recherche, publiés ou non, émanant des établissements d'enseignement et de recherche français ou étrangers, des laboratoires publics ou privés. 


\section{Graphical Abstract}

To create your abstract, type over the instructions in the template box below.

Fonts or abstract dimensions should not be changed or altered.

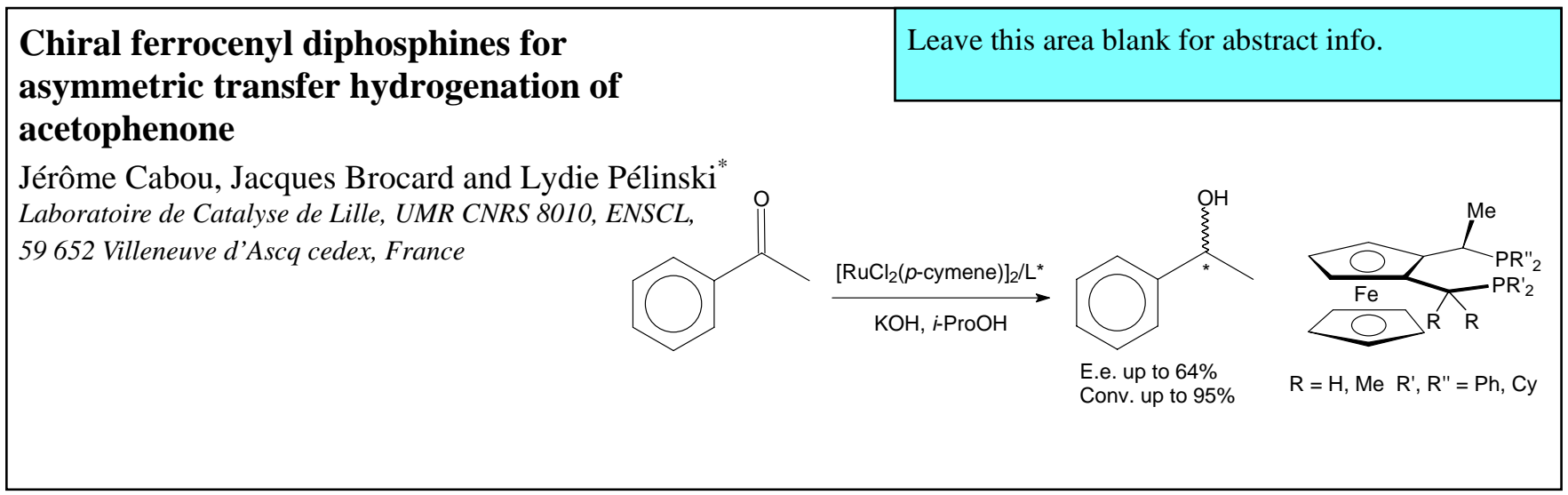




\title{
Chiral Ferrocenyl Diphosphines for Asymmetric Transfer Hydrogenation of Acetophenone
}

\author{
Jérôme Cabou, Jacques Brocard and Lydie Pélinski ${ }^{*}$ \\ Laboratoire de Catalyse de Lille, Catalyse Asymétrique et Polymérisation, \\ UMR CNRS 8010, ENSCL,59 652 Villeneuve d'Ascq cedex, France
}

\begin{abstract}
The synthesis of new optically pure ferrocenyl diphosphines have been realized from (R)-(+)- $N, N$ dimethylaminoethylferrocene. Particularly, dissymmetric ferrocenyl diphosphines have been synthesized. The diphosphines have been used as ligands in asymmetric transfer hydrogenation of acetophenone in the presence of Ru catalysts. (c) 2006 Elsevier Science. All rights reserved
\end{abstract}

Catalytic asymmetric hydrogenation of prochiral ketones to chiral alcohols using transition metal complexes has gained increasing interest during recent years. ${ }^{1}$ In particular, ruthenium-catalyzed asymmetric transfer hydrogenation using 2-propanol under basic conditions presents the advantages of a low cost, ease of handling and high solubility of 2-propanol as hydrogen donor reagent. ${ }^{2}$ Noyori developed an efficient and highly enantioselective ruthenium catalyst using diamines as chiral ligands. ${ }^{3}$ Other types of ligands such as amino alcohols, ${ }^{4}$ aminooxazolines, ${ }^{5}$ aminophosphines, ${ }^{6}$ diureas, ${ }^{7}$ and phosphine oxides ${ }^{8}$ have also been used with various levels of rates, yields and selectivities. In particular, only ferrocenyl ligands possessing oxazoline/phosphines, ${ }^{9}$ triphosphines, ${ }^{10}$ amino alcohols ${ }^{11}$ imine/phosphines, ${ }^{12}$ and diamines $^{13}$ have been studied. Also, to our best knowledge, the involvement of ferrocenyl diphosphines has not been reported so far. Moreover, Genêt reported a series of dibromodiphosphinoruthenium catalysts $\left(\left[\mathrm{RuP}_{2} \mathrm{Br}_{2}\right]\right.$, where $\mathrm{P}^{*}=$ diphosphine) for transfer hydrogenation of ketones, achieving good conversion in short reaction times. ${ }^{14}$ However, only moderate enantioselectivities (7$52 \%$ ee) has been obtained.

We have had an ongoing interest in the synthesis and use of optically active ligands in asymmetric catalysis, especially ferrocenyl amino alcohols. ${ }^{15}$ Herein we present the synthesis of new ferrocenyl diphosphines 1-5 (Figure 1) and the first results for asymmetric transfer hydrogenation of acetophenone catalyzed by $\mathrm{Ru}(\mathrm{II})$ complexes of these bidentate ligand system. Our initial efforts focused on screening a variety of ferrocenyl compounds in which chelating groups and stereogenic centers were varied in order to ascertain their effects on the reaction.
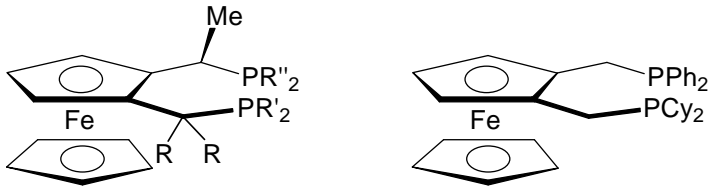

$$
\begin{array}{lll}
R=H, & R^{\prime}=R^{\prime \prime}=P h & \mathbf{1} \\
R=H, & R^{\prime}=R^{\prime \prime}=C y & \mathbf{2} \\
R=H, & R^{\prime}=P h, R^{\prime \prime}=C y & \mathbf{3} \\
R=M e & R^{\prime}=R^{\prime \prime}=P h & 4
\end{array}
$$

5

Figure 1.

Following a similar procedure as described by Fukuzawa, ${ }^{16}$ the ferrocenyl diphosphines $\mathbf{1}$ and $\mathbf{2}$ have been synthesized from $(R)-N, N$-dimethyl-1-ferrocenylethyl amine $\mathbf{6}$ (Scheme 1). ${ }^{17}$ Thus, the commercial ferrocenyl amine $\mathbf{6}$ has been converted to the amino alcohol 7 in two steps in a global yield of $88 \%$. The ortholithiation of 6 by $t$-BuLi followed by addition of DMF and the reduction by $\mathrm{NaBH}_{4}$ of the aldehyde led to 7. The acylation of the alcohol group was carried out in acetic anhydride in the presence of dimethylaminopyridine and triethylamine at room temperature to give $\mathbf{8}$ in $95 \%$ yield. The dimethylamino group was then substituted by an acetoxy residue in the

\footnotetext{
* Corresponding author. Tel.: +33-3-20434893; fax: +33-3-20436585; e-mail: lydie.pelinski@ensc-lille.fr.
} 

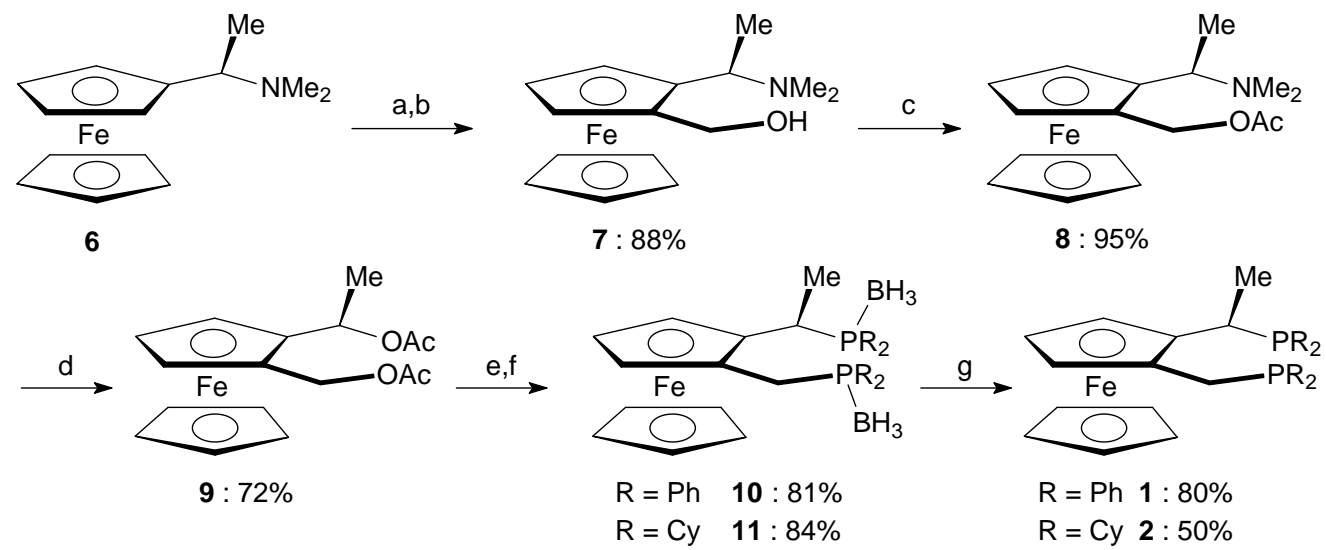

Scheme 1 Reagents and conditions: a) $t$-Buli, $\mathrm{Et}_{2} \mathrm{O}$ then DMF; b) $\mathrm{NaBH}_{4}, \mathrm{MeOH}$; c) $\mathrm{Ac}_{2} \mathrm{O}$, DMAP, $\mathrm{NEt}_{3}, \mathrm{RT}, 1 \mathrm{~h}$; d) $\mathrm{Ac}_{2} \mathrm{O}, 100^{\circ} \mathrm{C}, 45 \mathrm{~min}$; e) $\mathrm{HBF}_{4}, \mathrm{CH}_{2} \mathrm{Cl}_{2}$ then $\mathrm{HPR}_{2}, \mathrm{CH}_{2} \mathrm{Cl}_{2}$, RT; f) $\mathrm{BH}_{3} \cdot \mathrm{Me}_{2} \mathrm{~S}$, THF, RT, $1 \mathrm{~h}$; g) Morpholine for 1 or $\mathrm{HBF}_{4}$.OEt 2 , RT for 2, $12 \mathrm{~h}$.

presence of acetic anhydride at $100^{\circ} \mathrm{C}$ providing 9 in $72 \%$ yield. The diacetoxyferrocene $\mathbf{9}$ was then converted into diphosphines in the presence of $\mathrm{HBF}_{4}$ followed by addition of $\mathrm{HPR}_{2}$ in $\mathrm{CH}_{2} \mathrm{Cl}_{2}$ at room temperature. A protection of the diphosphines was necessary for a purification by silica gel column chromatography. Ferrocenyl protected diphosphines 10 and 11 were obtained in 81 and 84\% global yield respectively. The deprotection of the diphosphines by morpholine or $\mathrm{HBF}_{4} \cdot \mathrm{OEt}_{2}$ yielding respectively $\mathbf{1}$ and $\mathbf{2}$ was carried out just before use in catalysis.

The synthesis of the ferrocenyl diphosphine $3^{18}$ was carried out from the amino alcohol 7 (Scheme 2). Thus, the alcohol function was first transformed to diphenylphosphine group in the presence of $\mathrm{HBF}_{4}$ following by addition of $\mathrm{HPPh}_{2}$ at room temperature providing to aminophosphine 12. After substitution of dimethylamino group by $\mathrm{PCy}_{2}$ and protection by $\mathrm{BH}_{3}$, the protected diphosphine 13 was obtained in $65 \%$ global yield for the three steps. The deprotection of the diphosphine by $\mathrm{HBF}_{4} \cdot \mathrm{OEt}_{2}$ led to 3 in $73 \%$ yield.

According to the literature method, ${ }^{19}$ the optically pure amino alcohol 14, possessing only planar chirality, has been synthesized from $N, N$-dimethylaminomethylferro cene. Then, the analogous reactions as described previously for 3, have been realized from ferrocenyl compound 14 (Scheme 2). The protected diphosphine $\mathbf{1 6}$ has been obtained in 59\% global yield. The deprotection by $\mathrm{HBF}_{4} . \mathrm{OEt}_{2}$ of $\mathbf{1 6}$ leads to 5 in $50 \%$ yield. $^{20}$
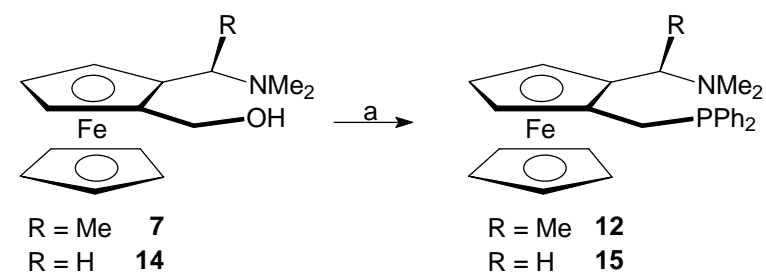

$\mathrm{R}=\mathrm{H} \quad 14$

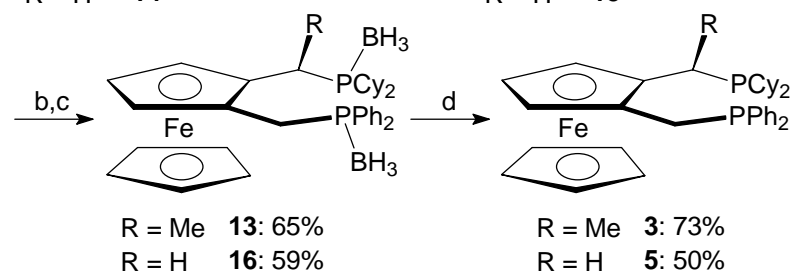

Scheme 2 Reagents and conditions: a) $\mathrm{HBF}_{4}, \mathrm{CH}_{2} \mathrm{Cl}_{2}$ then $\mathrm{HPPh}_{2}$, $\mathrm{CH}_{2} \mathrm{Cl}_{2}$; b) $\mathrm{HPCy}_{2}, \mathrm{AcOH}$, for $\mathrm{R}=\mathrm{Me}, 90^{\circ} \mathrm{C}, 1.45 \mathrm{~h}$ and for $\mathrm{R}=\mathrm{H}$, $120^{\circ} \mathrm{C}, 3 \mathrm{~h}$; c) $\mathrm{BH}_{3} \cdot \mathrm{Me}_{2} \mathrm{~S}$, THF, RT, 1 h; d) $\mathrm{HBF}_{4} \cdot \mathrm{OEt}_{2}, \mathrm{RT}, 12 \mathrm{~h}$.

The ferrocenyl diphosphines $\mathbf{4}$ has been synthesized from (R)- $N, N$-dimethyl-1-ferrocenylethylamine 6 (Scheme 3 ). ${ }^{21}$ Thus, the ortholithiation of $\mathbf{6}$ by $t$-BuLi followed by addition of diethylcarbonate led to $\mathbf{1 7}$ in $81 \%$ yield. The dimethylamino group was then substituted by an acetoxy residu in the presence of acetic anhydride at $100^{\circ} \mathrm{C}$ providing 18 in 80\% yield. The ferrocenyl dialcohol 19 was obtained quantitatively by the addition of an excess of $\mathrm{MeLi}$ on 18. The dialcohol was then converted into diphosphine 4 in the presence of $\mathrm{HBF}_{4}$ followed by addition of $\mathrm{HPPh}_{2}$ in $\mathrm{CH}_{2} \mathrm{Cl}_{2}$ at room temperature. The diphosphine $\mathbf{4}$ has been obtained in 36\% yield.

In order to examine the catalytic behavior of these new ferrocenyl ligands, transfer hydrogenation of acetophenone, using $\left[\mathrm{RuCl}_{2} \text { (p-cymene) }\right]_{2}$ and $i-\mathrm{PrOH} / \mathrm{KOH}$ mixture as the base, has been first investigated (Scheme 4). ${ }^{22}$ The preliminary results are summarized in Table 1. 


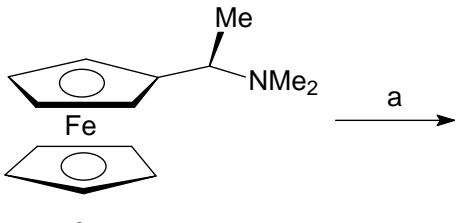

6

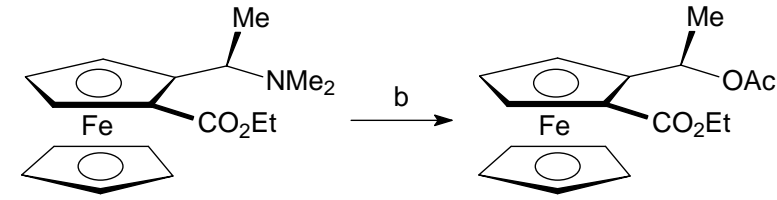

$18: 80 \%$

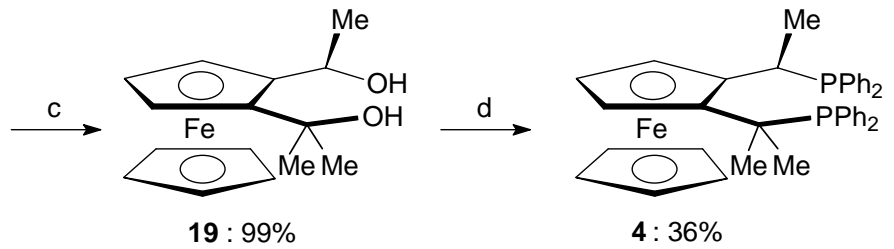

Scheme 3 Reagents and conditions: a) $t$-Buli, $\mathrm{Et}_{2} \mathrm{O}$ then $\mathrm{CO}(\mathrm{OEt})_{2}$; b) $\mathrm{Ac}_{2} \mathrm{O}, 100^{\circ} \mathrm{C}, 1 \mathrm{~h}$; c) $\left.\mathrm{MeLi}(6 \mathrm{eq}) ; \mathrm{d}\right) \mathrm{HBF}_{4}, \mathrm{CH}_{2} \mathrm{Cl}_{2}$ then $\mathrm{HPPh}_{2}, \mathrm{CH}_{2} \mathrm{Cl}_{2}, \mathrm{RT}$
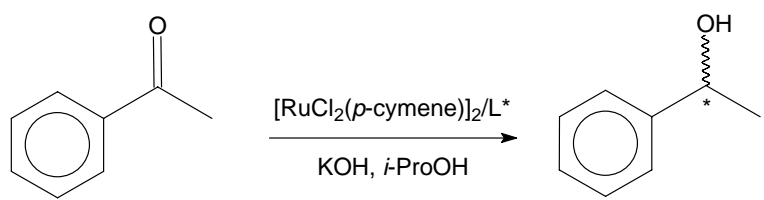

\section{Scheme 4}

Table 1. Asymmetric transfer hydrogenation of acetophenone in the presence of ligands $1-5^{\mathrm{a}}$

\begin{tabular}{llllll}
\hline Entry & $\mathrm{L}^{*}$ & $\begin{array}{c}\text { Time } \\
\min \end{array}$ & $\begin{array}{l}\text { Conversion }^{\mathrm{b}} \\
\%\end{array}$ & $\mathrm{Ee}^{\mathrm{c}} \%$ & Config. $^{\mathrm{d}}$ \\
\hline 1 & $\mathbf{1}$ & 10 & 30 & 61 & $R$ \\
2 & $\mathbf{1}$ & 50 & 60 & 55 & $R$ \\
$3^{\mathrm{e}}$ & $\mathbf{1}$ & 2 & 95 & 40 & $R$ \\
$4^{\mathrm{f}}$ & $\mathbf{1}$ & 10 & 51 & 64 & $R$ \\
5 & $\mathbf{2}$ & 60 & 66 & $19^{\mathrm{g}}$ & $S$ \\
6 & $\mathbf{3}$ & 12 & 41 & 20 & $S$ \\
7 & $\mathbf{4}$ & 130 & 71 & 50 & $R$ \\
8 & $\mathbf{5}$ & 270 & 5 & 29 & $S$
\end{tabular}

${ }^{a}$ Reactions were carried out by using $2 \mathrm{mmol}$ of acetophenone in the presence of $\left[\mathrm{Ru}(p \text {-cymene }) \mathrm{Cl}_{2}\right]_{2} \quad$ (substrate/Ru $\left.=100\right)$, the ligand (ligand/Ru = 2) and $\mathrm{KOH}(0.1 \mathrm{mmol})$. For details see reference 16.

b The progression of the reaction was monitored by GC analysis with a Chiraldex capillary column.

c. Determined by GC analysis with a Chiraldex capillary column.

d. Absolute configurations were determined by comparing the sign of the optical rotations with the literature ones.

e. Reaction performed at $80^{\circ} \mathrm{C}$.

${ }^{\mathrm{f}}$. Reaction performed in using ligand/Ru $=1$.

g. Maximal e.e.

The first catalytic system investigated was carried out in the presence of ligand 1, presenting carbon centered and planar chiralities. As shown in Table 1, a modest enantioselectivity (61\% ee, entry 1$)$ was observed in presence of ferrocenyl diphosphine 1. Moreover, only 30\% of conversion was obtained after $10 \mathrm{~min}$.
The reversibility of the asymmetric transfer hydrogenation of ketones to secondary alcohols with 2-propanol frequently deteriorates the enantiomeric purity of the chiral products. Indeed, a decrease of enantiomeric excess was observed during the reaction time in presence of ligand $\mathbf{1}$. $61 \%$ ee was obtained after $10 \mathrm{~min}$ and $55 \%$ ee after $50 \mathrm{~min}$ (entries 1 and 2).

Performing the hydrogenation at $80^{\circ} \mathrm{C}$ led to a decrease of the enantioselectivity and an increase of activity providing 1-phenylethanol with $40 \%$ ee and $95 \%$ yield after only 2 min (entry 3).

The enantioselectivity was practically unaffected by changing the ratio ligand/Ru from 2 to 1 (compare entries 2 and 4).

It appears that the presence of the diphenyl group in the ligand is essential for a good enantioselectivity. Replacement of the diphenyl by a dicyclohexyl group on the phosphorus atom led to a reduction of the enantioselectivity and inverted the sense of the induction. As such, (S) 1-phenylethanol was obtained in 19\% of ee in the presence of ligand 2 (entry 5). This value corresponds to the maximal enantiomeric excess at $60 \mathrm{~min}$.

In ligand 4, the replacement of the hydrogen atom on the lateral chain by two methyl groups induced a diminution of enantioselectvity (compare entries 1 and 7, 61\% ee for 1 vs $50 \%$ ee for 4 ).

It also seems that, for this type of ligand, the presence of a chiral center adjacent to the diphosphino group has a major influence on the catalytic activity. Thus, a low activity (5\% after $270 \mathrm{~min}$, entry 8) has been obtained in the presence of the ferrocenyl diphosphine $\mathbf{5}$, possessing only planar chirality.

In summary, this paper describes the synthesis of a series of new ferrocenyl diphosphines and their use as ligands for asymmetric transfer hydrogenation of acetophenone catalyzed by $\mathrm{Ru}(\mathrm{II})$ complexes. The results obtained for the ligand 1 represents the best one from the literature with this type of catalytic system using ferrocenyl diphosphines as 
ligands. The improvement of the ligand design is under study.

\section{Acknowledgments}

The authors gratefully thank the "Ministère de la Recherche et de la Technologie" ands the "Centre National de la Recherche Scientifique" for financial support and Francine AgbossouNiedercorn and Isabelle Suisse for helpfull discussions.

\section{References}

1. (a) Noyori, R. Asymmetric Catalysis in Organic Synthesis; John Wiley: New York, 1994. (b) Catalytic Asymmetric Synthesis; Ojima, I., Ed.; VCH: New-York, 2000.

2. (a) Zassinovitch, G.; Maestroni, G.; Gladiali, S. Chem Rev. 1992, 92, 1051. (b) Palmer, M. J.; Wills, M. Tetrahedron: Asymmetry, 1999, 10, 2045.

3. (a) Noyori, R.; Hashiguchi, S. Acc. Chem. Res. 1997, 30, 97. (b) Haak, K. J.; Hashiguchi, S.; Fujii, A.; Ikariya, T.; Noyori, R. Angew. Chem., Int. Ed. Engl. 1997, 36, 285.

4. (a) Alonso, D. A.; Nordin, S. J. M.; Roth, P.; Tarnai, T.; Andersson, P. G.; Thommen, M.; Pittelkow, U. J. Org. Chem. 2000, 65, 3116. (b) Palmer, M. J.; Walsgrove, T.; Wills, M. J. Org Chem. 1997, 62, 5226.

5. Jiang, Y.; Jiang, Q.; Zhang, X. J. Am. Chem. Soc. 1998, 120, 3817.

6. (a) Léautey, M.; Jubault, P.; Pannecoucke, X.; Quirion, J.-C. Eur. J. Org. Chem. 2003, 3761. (b) Gao, J.-X.; Ikariya, T.; Noyori, R. Organometallics 1996, 15, 1087.

7. Gamez, P.; Dunjic, B.; Lemaire, M. J. Org. Chem. 1996, 61, 5196.

8. Maj, A. M.; Pietrusiewicz, K. M.; Suisse, I.; Agbossou, F.; Mortreux, A. Tetrahedron: Asymmetry 1999, 10, 831.

9. Sammakia, T.; Stangeland, E. L. J. Org. Chem. 1997, 62, 6104.

10. Barbaro, P.; Bianchini, C.; Togni, A. Organometallics 1997, 16, 3004.

11. Patti, A.; Pedotti, S. Tetrahedron: Asymmetry 2003, 14, 597.

12. Dai, H.; Hu, X.; Chen, H.; Bai, C.; Zheng, Z. Tetrahedron: Asymmetry 2003, 14, 1467.

13. Schwink, L.; Ireland, T.; Püntener, K.; Knochel, P. Tetrahedron: Asymmetry 1998, 9, 1143.

14. Genêt, J.-P.; Ratovelomanana-Vidal, V.; Pinel, C. Synlett 1993, 7, 478.

15. Bastin, S.; Ginj, M.; Brocard, J.; Pélinski, L.; Nowogrocki, G. Tetrahedron: Asymmetry 2003, 14, 1701.

16. Fukuzawa, S.-I.; Tsuchiya, D.; Sasamoto, K.; Hiramo, K.; Ohtaguchi, M. Eur. J. Org. Chem. 2000, 2877.

17. 1: ${ }^{1} \mathrm{H}$ NMR $\left(\mathrm{CDCl}_{3}\right) \delta 7.5-7.0(\mathrm{~m}, 20 \mathrm{H}), 4.1(\mathrm{~s}, 5 \mathrm{H}), 4.0$ (m, 1H), $3.9(\mathrm{~m}, 1 \mathrm{H}), 3.8(\mathrm{~m}, 1 \mathrm{H}), 3.3(\mathrm{~m}, 1 \mathrm{H}), 2.6(\mathrm{~d}, J$ $=15.5 \mathrm{~Hz}, 1 \mathrm{H}), 2.0(\mathrm{dd}, J=15.5$ and $4.2 \mathrm{~Hz}, 1 \mathrm{H}), 1.5$ (dd, $J=7.1$ and $13.9 \mathrm{~Hz}, 3 \mathrm{H}) .{ }^{31} \mathrm{P}$ NMR $\left(\mathrm{CDCl}_{3}\right) \delta 5.8$, 18.2.

2: ${ }^{1} \mathrm{H}$ NMR $\left(\mathrm{CDCl}_{3}\right) \delta 4.3(\mathrm{~m}, 1 \mathrm{H}), 4.1(\mathrm{~s}, 5 \mathrm{H}), 4.0(\mathrm{~m}$, $1 \mathrm{H}), 3.9(\mathrm{~m}, 1 \mathrm{H}), 2.8(\mathrm{~m}, 1 \mathrm{H}), 2.6-2.4(\mathrm{~m}, 2 \mathrm{H}), 2.0-1.0$ $(\mathrm{m}, 47 \mathrm{H}) .{ }^{31} \mathrm{P} \mathrm{NMR}\left(\mathrm{CDCl}_{3}\right) \delta 12.2,7.9$.

18. 3: ${ }^{1} \mathrm{H}$ NMR $\left(\mathrm{CDCl}_{3}\right) \delta 7.5-7.2(\mathrm{~m}, 10 \mathrm{H}), 4.0(\mathrm{~s}, 5 \mathrm{H}), 4.0$ (m, 1H), $3.9(\mathrm{~m}, 2 \mathrm{H}), 3.4(\mathrm{~m}, 1 \mathrm{H}), 3.1(\mathrm{~m}, 1 \mathrm{H}), 2.9(\mathrm{~m}$, 1H), 1.9-1.0 (m, 25H). ${ }^{31} \mathrm{P}$ NMR $\left(\mathrm{CDCl}_{3}\right) \delta 12.0,-17.5$.
19. Nicolosi, G.; Patti, A.; Morrone, R.; Piattelli, M. Tetrahedron: Asymmetry 1994, 5, 1275.

20. 5: ${ }^{1} \mathrm{H}$ NMR $\left(\mathrm{CDCl}_{3}\right) \delta$ 7.5-7.2 (m, 10H), $4.1(\mathrm{~m}, 1 \mathrm{H})$, $4.0(\mathrm{~s}, 5 \mathrm{H}), 3.8(\mathrm{~m}, 1 \mathrm{H}), 3.7(\mathrm{~m}, 1 \mathrm{H}), 3.2(\mathrm{~d}, J=14.4$ $\mathrm{Hz}, 1 \mathrm{H}$ ), 3.1 (d, $J=14.4 \mathrm{~Hz}, 1 \mathrm{H}), 2.5$ (dd, $J=15.2$ and $1.7 \mathrm{~Hz}, 1 \mathrm{H}), 2.3(\mathrm{dd}, J=15.2$ and $1.7 \mathrm{~Hz}, 1 \mathrm{H}), 1.8-1.1$ (m, 22H). ${ }^{31} \mathrm{P} \mathrm{NMR}\left(\mathrm{CDCl}_{3}\right) \delta$-5.1, -16.0.

21. 4: ${ }^{1} \mathrm{H} \mathrm{NMR}\left(\mathrm{CDCl}_{3}\right) \delta 7.7-6.9(\mathrm{~m}, 20 \mathrm{H}), 4.1(\mathrm{~s}, 5 \mathrm{H}), 4.1$ (m, 1H), $4.0(\mathrm{~m}, 1 \mathrm{H}), 3.9(\mathrm{~m}, 1 \mathrm{H}), 3.2(\mathrm{~m}, 1 \mathrm{H}), 1.6(\mathrm{~d}, J$ $=14.2 \mathrm{~Hz}, 3 \mathrm{H}), 1.5(\mathrm{~m}, 3 \mathrm{H}), 1.4(\mathrm{~d}, J=3.4 \mathrm{~Hz}, 3 \mathrm{H}) .{ }^{31} \mathrm{P}$ $\operatorname{NMR}\left(\mathrm{CDCl}_{3}\right) \delta 12.9,6.8$.

22. Typical experimental procedure: the appropriate amount of ligand $(0.02 \mathrm{mmol})$ was added to the catalyst precursor $(0.01 \mathrm{mmol}) \quad\left[\mathrm{Ru}(p \text {-cymene }) \mathrm{Cl}_{2}\right]_{2}$ in dry freshly distilled 2-propanol $(5 \mathrm{~mL})$ and stirred at $80^{\circ} \mathrm{C}$ for $20 \mathrm{~min}$ under nitrogen. After allowing the orange solution to cool to room temperature, a solution of acetophenone (2 mmol) in 2-propanol $(14 \mathrm{~mL})$ and $\mathrm{KOH}$ (1 mL, $0.1 \mathrm{M}$ in 2-propanol) was added. The resulting solution was stirred at $20^{\circ} \mathrm{C}$ and the reaction was monitored by GC. 